\title{
Ways to Increase Investment Potential in Samarkand Region
}

\author{
Shirin Nodirovna Mirzaeva \\ Assistant-Teacher of the Chair of Real economics, Samarkand Institute of Economics and Service, Uzbekistan \\ http://dx.doi.org/10.18415/ijmmu.v9i2.3542
}

\begin{abstract}
The article highlights the issues related to the regional specifics of investment activities in the Samarkand region. Formation and improvement of investment attraction mechanisms for the effective conduct of investment activities in the region, presentation of promising project proposals for a business wishing to invest, development and systematic implementation of high-quality projects, mutually beneficial cooperation with foreign partners, scientifically based proposals and recommendations. to create favorable conditions for the activities of investors, to attract investments.
\end{abstract}

Keywords: Investment Activity; Investment Fund; Project; Subject; Mechanism; Local and Foreign Investment; Free Economic Zones; Investment Activity; Securities

\section{Introduction}

The stability of the economy of our country and its individual regions, social, economic and political development are inextricably linked with investment policy. Attracting investments has a special place in reducing economic disparities and inconsistencies between the regions of the country. Effective use of these opportunities will pave the way for the rational use of all available resources in the regions and the structural improvement of the regional economy.

Looking at the experience of foreign countries, foreign investment is one of the main mechanisms to ensure the sustainable development of the country's economy.

Positive results in the economy provide an opportunity to systematically address the problems that have accumulated in the social sphere. We all need to understand this deeply and organize our work on this basis. In order to attract more foreign investment, we must take measures to demonstrate the investment potential of our country, which is one of the most pressing issues in our daily lives. [1]

Expanding the raw material base and deepening its processing in the country, increasing the production of competitive finished products with high added value, attracting foreign direct investment and high technology in the economy, socio-investment projects. determines the relevance of the chosen topic in the implementation of tasks such as ensuring economic efficiency, creating high-income jobs on this basis and accelerated socio-economic development of the regions. 
Analysis of the literature on the subject:

Investments, their active attraction, creation of a favorable investment climate, organization of factors influencing investment activity in the development of the national economy, including direct, foreign investment and the establishment of enterprises with their participation, the role and importance of investment in the development of regional economic activity .Eclund [3], EDDolan and DS Lindsay [4], U.Sharp [5], L.Gitman, M.Djonk [6], K.Macconell, S.Brew [7], R.Samuelson, V.Nordhaus [8] Types of investment activities and their financing sources, scientific and practical bases of classification and development of investments, conducted research in investment activities and investment areas.

Also, the leading scientists of the republic D.Gozibekov [9], B.A.Abdukarimov, A.N. Jabriyev, M.K. Pardayevl [10], D. Tadjibayeva [11], and others conducted research.

\section{Approaches to Highlighting the Concept of Investment}

\begin{tabular}{|c|c|c|}
\hline Authors & Definition & \\
\hline $\begin{array}{l}\text { Wikipedia, the free } \\
\text { encyclopedia }\end{array}$ & $\begin{array}{l}\text { Derived from the word "investment" (from the } \\
\text { German "Investio", Latin "Investio"), which is } \\
\text { mainly interpreted as the sum of long-term } \\
\text { investments in production, ie the sum of costs. } \\
\text { Investments are all types of wealth that are spent } \\
\text { over a period of time in various sectors of the } \\
\text { economy to meet unlimited needs, effectively } \\
\text { using limited opportunities by the state, legal } \\
\text { entities and individuals (investors) in order to } \\
\text { make a profit or gain social benefits. Most people } \\
\text { who don't understand economics think that } \\
\text { investment is a debt. Investments are not taken into } \\
\text { account when calculating public debt. [2] }\end{array}$ & $\begin{array}{l}\text { https://uz.wikipedia.org/wi } \\
\text { ki/Investitsiya }\end{array}$ \\
\hline C. Eclund & $\begin{array}{l}\text { Investing is something that is left for tomorrow to } \\
\text { have more consumption conditions in the future. } \\
\text { Some of it is now unused consumer goods, while } \\
\text { others are resources to expand production. [3] }\end{array}$ & $\begin{array}{l}\text { Class Eklund. Effective } \\
\text { economy: Swedish model. } \\
\text { M. Economics 1991, 96p }\end{array}$ \\
\hline $\begin{array}{l}\text { E.Dj. Dolan and } \\
\text { D.S. Lindsey }\end{array}$ & $\begin{array}{l}\text { The essence of investment is "the growth of capital } \\
\text { in the emerging economic system, the increase in the } \\
\text { supply of productive resources in which people } \\
\text { operate." [4] }\end{array}$ & $\begin{array}{l}\text { Dolan E.Dj., Lindsey } \\
\text { D.YE. Microeconomics. } \\
\text { Spb., 1994.-448 p. }\end{array}$ \\
\hline U. Sharp & $\begin{array}{l}\text { The investment is a divorce today with a certain } \\
\text { amount of money to invest even more in the future. } \\
{[5]}\end{array}$ & $\begin{array}{l}\text { http://el.tfi.uz/images/Kari } \\
\text { mqulov_BMI_uz_cd153.p } \\
\text { df }\end{array}$ \\
\hline L.Gitman, M.Djonk & $\begin{array}{l}\text { Investment is the placement of capital in such a } \\
\text { way that its value is maintained, increased and } \\
\text { brings a positive amount of income. [6] }\end{array}$ & arxiv.uz \\
\hline $\begin{array}{l}\text { K.Makkonell, } \\
\text { S.Bryu }\end{array}$ & $\begin{array}{l}\text { Investment is the increase in material resources, } \\
\text { the accumulation of means of production and the } \\
\text { cost of production. [7] }\end{array}$ & arxiv.uz \\
\hline $\begin{array}{l}\text { R.Samuelson, } \\
\text { V.Nordxaus }\end{array}$ & $\begin{array}{l}\text { Investment is an economic situation, which means } \\
\text { giving up consumer spending today in order to } \\
\text { expand production in the future. In it, the funds are } \\
\text { directed to tangible or intangible capital. } \\
\text { According to financiers, investing means buying } \\
\text { securities. [8] }\end{array}$ & arxiv.uz \\
\hline
\end{tabular}




\begin{tabular}{|c|c|c|}
\hline D.Gozibekov & $\begin{array}{l}\text { The essence of investment is to obtain funds from } \\
\text { clear and reliable sources, to mobilize them } \\
\text { reasonably, to maintain the value of capital, taking } \\
\text { into account the level of risk, and to achieve the } \\
\text { intended effect. [9] }\end{array}$ & arxiv.uz \\
\hline $\begin{array}{l}\text { B.A.Abdukarimov, } \\
\text { A.N. Jabriyev, M.K. } \\
\text { Pardayev }\end{array}$ & $\begin{array}{l}\text { "An investment is an investment in financial } \\
\text { (monetary) or real capital. It is carried out in the form } \\
\text { of cash, credit, securities and is invested in movable, } \\
\text { immovable property, intellectual property, the right to } \\
\text { goods and other valuables, i.e. applied to all assets of } \\
\text { the enterprise. [10] }\end{array}$ & $\begin{array}{l}\text { Abdukarimov B.A. etc. } \\
\text { Enterprise economics } \\
\text { (textbook) .- T.: } \\
\text { Science, 2005. } 241 \mathrm{~b} .\end{array}$ \\
\hline D. Tadjibayeva & $\begin{array}{l}\text { Investment means financial resources for future } \\
\text { results: expansion of production and renovation, } \\
\text { improvement of product and service quality, training } \\
\text { of qualified specialists and scientific research is } \\
\text { understood. [11] }\end{array}$ & $\begin{array}{l}\text { Tadjibayev D. } \\
\text { Economic theory } \\
\text { (second book). - T.: } \\
\text { Sharq, 2003-79p }\end{array}$ \\
\hline $\begin{array}{l}\text { The Law of the } \\
\text { Republic of } \\
\text { Uzbekistan was } \\
\text { adopted in } 1998 \\
\text { 2-Article }\end{array}$ & $\begin{array}{l}\text { tangible and intangible benefits and rights to } \\
\text { investments in economic and other activities. [12] }\end{array}$ & $\begin{array}{l}\text { https://lex.uz/ru/docs/- } \\
29905\end{array}$ \\
\hline $\begin{array}{l}\text { The Law of the } \\
\text { Republic of } \\
\text { Uzbekistan was } \\
\text { adopted in } 2019 \\
\text { 3-Article }\end{array}$ & $\begin{array}{l}\text { investments are material and intangible assets and } \\
\text { rights to them, including rights to intellectual } \\
\text { property, which are invested by the investor in the } \\
\text { social sphere, business, scientific and other activities } \\
\text { on the basis of risks. [13] }\end{array}$ & $\begin{array}{l}\text { https://lex.uz/docs/- } \\
4664142\end{array}$ \\
\hline
\end{tabular}

Based on the above, the results of theoretical research of foreign and domestic scientists on the nature of investment, we came to the following conclusion: tangible and intangible assets and rights to them, including rights to intellectual property, which are included in the objects of activity on the basis of risks.

In our view, Investment is capital that has not yet been packaged, but invested in the means of production. According to their financial form, they are assets invested in economic activities for profit.

\section{Research Methodology}

In the course of our research, the methods of statistical processing, analysis, expert assessment, systematic approach, comparison, comparative analysis of the volume of investments in fixed assets in the regions of the Republic of Uzbekistan by grouping data were used.

\section{Analysis and Results}

At present, one of the most important tasks in the field of economic development is the creation of favorable conditions for attracting foreign investment in the economy of our country, the introduction of practical mechanisms for their legal protection and further improvement of the investment climate. Therefore, for 2021-2023, 1,277 investment projects worth more than 109 trillion soums have been formed. Of this, about $\$ 4.9$ billion is foreign investment and loans. ${ }^{1}$

\footnotetext{
${ }^{1}$ https://stat.uz/uz/rasmiy-statistika/investments 
Expanding the raw material base and deepening its processing in the country, increasing the production of competitive high-value-added finished products, attracting foreign direct investment and high technology in the economy, ensuring the socio-economic efficiency of investment projects, on this basis A number of measures are being taken to create jobs and accelerate the socio-economic development of the regions. In particular, according to the State Statistics Committee, as of January 1, 2021, the volume of investments in fixed assets by small enterprises and micro-firms amounted to 75.8 trillion soums. som. This is 6.3 trillion more than in the same period last year. som.

By type of economic activity, the volume of investments in fixed assets (as of January-September 2021) was $23.8 \%$ in manufacturing, $9 \%$ in agriculture, forestry and fisheries, $11.6 \%$ in wholesale and retail trade, $7 \%$ in housing construction, $1 \%$ in transportation and storage, $2.1 \%$ in total services and $40 \%$ in other activities ${ }^{2}$.

On February 25, 2020, the 101st resolution of the governor of Samarkand region on the implementation of the regional investment program for 2020-2022 was adopted. According to the press service of the Department of Investment and Foreign Trade of the region, Samarkand will receive 5.5 trillion soums in 2020. A total of 1,248 investment projects were implemented and 12,058 new jobs were created. In particular: 3.0 trillion soums for 325 industrial projects. 5,417 new jobs were invested in the amount of KGS;

1.2 trillion for 423 projects in the field of services. 3,665 new jobs were invested in the amount of KGS;

1.3 billion soums for 500 projects in agriculture soms were invested and 2,976 new jobs were created.

On October 2, 2020, the Action Strategy adopted an order of the governor of Samarkand region aimed at implementing the tasks of improving the system of state and society building and systematically and effectively organizing the promotion of investment and economic potential of the region to foreign partners.

According to the order (www.invest.gov.uz) "Investment Portal" was created. To this end, the Investment and Foreign Trade Department has attached staff responsible for providing reliable data.

In assessing the innovative potential of the regions, along with the innovative potential of the region, its economic growth, indicators that determine the policy of the state in the development of the region and important ways to attract investment in the region are used.

According to the State Statistics Committee of the Republic of Uzbekistan, the investments in fixed assets by regions (growth rate, in\%) by regions show the following indicators (Table 1).

Table 1: Decreased Investments in Fixed Assets (Growth Rate, In \%)

\begin{tabular}{|l|l|l|l|}
\hline & $\mathbf{2 0 1 9}$-year & $\mathbf{2 0 2 0}-$ year & $\mathbf{2 0 2 1}$-year january-september \\
\hline Republic of Uzbekistan & $\mathbf{1 3 8 , 1}$ & $\mathbf{9 5 , 6}$ & $\mathbf{1 0 5 , 0}$ \\
\hline $\begin{array}{l}\text { The Republic of } \\
\text { Karakalpakstan }\end{array}$ & 100,3 & 69,9 & 100,6 \\
\hline Regions: & & & \\
\hline Andijan & 113,7 & 110,6 & 111,5 \\
\hline Bukhara & 60,6 & 104,7 & 125,1 \\
\hline Jizzakh & 158,1 & 147,4 & 98,2 \\
\hline Kashkadaryao & 112,4 & 76,5 & 67,9 \\
\hline Navai & 188,0 & 77,1 & 84,7 \\
\hline Namangan & 178,1 & 88,0 & 102,9 \\
\hline Samarkand & 131,4 & 128,8 & 119,4 \\
\hline
\end{tabular}

2 https://stat.uz/uz/rasmiy-statistika/investments 


\begin{tabular}{|l|l|l|l|} 
Surkhandarya & 164,2 & 77,4 & 124,2 \\
\hline Syrdarya & 131,0 & 111,2 & 100,4 \\
\hline Tashkent & 139,9 & 92,2 & 117,8 \\
\hline Fergana & 145,9 & 113,5 & 103,1 \\
\hline Khorezm & 111,7 & 92,7 & 135,2 \\
\hline Tashkent city & 138,2 & 108,6 & 119,1 \\
\hline
\end{tabular}

As can be seen from the table, among the regions in Samarkand in January-September 2021, the ratio of investments in fixed assets amounted to $119.4 \%$, which is second only to Khorezm and Surkhandarya regions.

During the visit of the President of the Republic of Uzbekistan Sh.M.Mirziyoyev to Samarkand region on April 15-16, 2021, as a result of the implementation of projects worth 30 trillion 450 billion soums for the development of new industries, services and agriculture in the region in 2021-2022 jobs were created. In order to further develop industrial production in the region, practical work is being carried out to establish branches of the Urgut Free Economic Zone and transform each district into a zone of modern specialized innovations and investments. Investments in fixed assets in Samarkand region in January-September 2021 amounted to a total of 12170.8 billion soums. som. (Table 2) We can see their share by districts in the table below.

Table 2: Investments in fixed assets in Samarkand region January-September 2021

\begin{tabular}{|l|l|l|}
\hline № & Regions: & Percentage by region (percent): \\
\hline 1. & Samarkand city & 37.1 \\
\hline 2. & Kattakurgan ditrict & 4.0 \\
\hline 3. & Akdarya district & 2.7 \\
\hline 4. & Bulungur district & 2.4 \\
\hline 5. & Jomboy district & 2.1 \\
\hline 6. & Ishtikhon district & 2.7 \\
\hline 7. & Kattakurgan district & 2.0 \\
\hline 8. & Kushrabat district & 5.0 \\
\hline 9. & Narpay district & 1.8 \\
\hline 10. & Payarik district & 2.7 \\
\hline 11. & Pastdargam district & 5.9 \\
\hline 12. & Pakhtachi district & 3.1 \\
\hline 13. & Samarkand district & 15.5 \\
\hline 14. & Nurabad district & 4.0 \\
\hline 15. & Urgut district & 5.2 \\
\hline 16. & Taylak district & 3.7 \\
\hline
\end{tabular}

The table above shows that in Samarkand region (37.1) and Samarkand district (15.5) the amount of investment in fixed assets is higher than in other districts. But in the rest of the region, these figures are almost below average. This indicates the need to increase the amount of investments in fixed assets in these regions as well.

\section{Conclusion and Suggestions}

In our opinion, today we need to do the following to attract investment to the region:

First, the improvement of the banking and credit system. 
Second, to further strengthen the protection of the rights of investors who invest.

Third, remove bureaucratic hurdles.

In summary, in order to increase investment potential in Samarkand region, to attract investments to each of the regions of the region, to present promising project proposals for businesses wishing to invest, to systematically ensure the development and implementation of quality projects, mutually beneficial cooperation with foreign partners. it will be necessary to create favorable conditions for their activities and develop measures to attract investment.

\section{References}

Abdukarimov B.A. etc. (2005) Enterprise economics (textbook). T.: Science. p 241.

Address of the President of the Republic of Uzbekistan Shavkat Mirziyoyev to the Oliy Majlis. People's Word, December 29, 2018 № 271-272 (7229-7230).

Class Eklund. (1991) Effective economy: Swedish model. M. Economics. p 96.

Dolan E.Dj., Lindsey D.YE. (1994) Microeconomics. Spb. p 448.

Fayziev Sh.N., Hodjaeva M.N., Davlyatov H.M. (2011) Investment audit and evaluation. Textbook. Tashkent, Uzbekistan. p 146.

Imomov H.H. (2010) Investment organization and financing. Textbook. Tashkent, Uzbekistan. p 188.

Karlibayeva R.X. (2011) Investment organization and financing. Textbook. Tashkent, Uzbekistan. p 124.

Lech Kurowski, David Sussman. (2004) Investment Project Design: A Guide to Financial and Economic Analysis O'Connor 62 Whitney Drive, UK London, UK.

Lutfullaevich, Y. G. (2020). Impact of inflation on R\&D investment flow: Case of five Countries. International Journal of Scientific and Technology Research, 9(1), 1970-1974.

Podsorin V.A. (2011) Economic evaluation of investments. Textbook. Moscow. MIIT. p 116.

Tadjibayev D. (2003) Economic theory (second book). T.: Sharq. p 79.

Yoziev, G. L. (2021). Conceptual approaches to building a perspective model of national innovation systems: Lessons for Uzbekistan. South Asian Journal of Marketing \& Management Research, 11(3), $46-52$.

\section{Copyrights}

Copyright for this article is retained by the author(s), with first publication rights granted to the journal.

This is an open-access article distributed under the terms and conditions of the Creative Commons Attribution license (http://creativecommons.org/licenses/by/4.0/). 